\title{
Physical Properties of Thermally Modified Juvenile and Mature Wood of Hevea brasiliensis (Euphorbiaceae)
}

\author{
Fred Willians Calonego ${ }^{1}$ (D) 0000-0002-1597-5586 \\ Elias Taylor Durgante Severo ${ }^{1}$ (i) 0000-0002-6024-0490 \\ João Vicente de Figueiredo Latorraca ${ }^{2}$ (1) 0000-0002-5969-5199 \\ Brian H. Bond ${ }^{3}$ (1) 0000-0001-6712-8250
}

\begin{abstract}
Exposing timber to temperatures approaching $200{ }^{\circ} \mathrm{C}$ causes thermal modification and changes its characteristics. This study evaluates the effect of various levels of thermal treatment on the physical properties of juvenile and mature wood from rubber tree (Hevea brasiliensis). Boards taken from 53-year-old rubber trees were thermally modified at up to $220^{\circ} \mathrm{C}$. Thermal treatment caused decreases on the oven-dried density, equilibrium moisture content, and swellings on juvenile and mature woods of $H$. brasiliensis. Influence of thermal modification at 180 $200{ }^{\circ} \mathrm{C}$ in juvenile wood was lower than in mature wood, whereas the treatment at $220^{\circ} \mathrm{C}$ caused a greater variation in properties of juvenile wood. The thermally modified wood is a suitable product for use in environments with high levels of relative humidity.
\end{abstract}

Keywords: thermal modification, rubber wood, maximum swellings, density of wood, equilibrium moisture content.

\section{INTRODUCTION AND OBJECTIVES}

Hevea brasiliensis (rubber tree) is a tree native to Brazil and is planted in many Asiatic countries for the production of latex (Severo et al., 2016). In Brazil, the commercial reforestation area of rubber trees is 229,059 ha (IBÁ, 2015). However, after 30 years, a decline in latex production makes further tapping of the trees uneconomical (Severo et al., 2016). Most plantations are from the State of São Paulo with federal government tax breaks.

In the past, felled rubber trees were either burned on the spot or used as fuel for steam engines, brick making or latex curing. Its favorable qualities and light color make a good substitute for many species (Ratnasingam \& Ioras, 2012; Severo et al., 2016). Rubber wood is now one of the major resources for making furniture for export and for the production of panel products, such as particleboard, fiberboard (MDF), wood fiber cement-bonded particleboard, and plywood (Severo et al., 2016).
Variation in the properties of rubber wood occurs due to several factors, such as tree species, silviculture, and especially wood anatomy. Juvenile wood is also called pith wood or core wood and is the wood formed near the tree center, displaying a cylindrical shape with a diameter almost uniform from the base of the stem to the top (Bao et al., 2001; Calonego et al., 2005; Ferreira et al., 2011; Palermo et al., 2015). It differs from mature wood (outer wood) on account of several properties, including: chemical properties, fiber length, densities, and dimensional stability (Bao et al., 2001; Calonego et al., 2005; Calonego et al., 2014; Latorraca et al., 2011; Lobão et al., 2012; Severo et al., 2013; Severo et al., 2016; Palermo et al., 2015).

There are numerous hypotheses about the cause of juvenile wood. This type of wood is formed during the initial phase of the tree's life by cambium regions, which are influenced by the apical meristem activity (Bendtsen, 1978; Cown, 1992). According to Bendtsen (1978) and Cown (1992), juvenile wood is controlled by the production of auxin in the tree

\footnotetext{
${ }^{1}$ Universidade Estadual Paulista Júlio de Mesquita Filho (UNESP), Botucatu, SP, Brasil

${ }^{2}$ Universidade Federal Rural do Rio de Janeiro (UFRRJ), Seropédica, RJ, Brasil

${ }^{3}$ Virginia Polytechnic Institute and State University (VPI), Blacksburg, VA, United States
} 
crown and results from close proximity to the foliage. Thus, the most accepted concept is that it is directly related to the age of the cambium that determines whether it will be formed juvenile, transition, or mature wood.

Fiber length in juvenile wood obtained from 50-year-old $H$. brasiliensis is $1.26 \mathrm{~mm}$, whereas in mature wood, it is $1.51 \mathrm{~mm}$. Anatomical characterization of this species showed the juvenile wood is confined between 40 and $55 \mathrm{~mm}$ from the pith (Ferreira et al., 2011).

Air-dried density of wood near the pith of 9-year-old H. brasiliensis RRIM 2020 clone ranges between 0.50 and $0.58 \mathrm{~g} \mathrm{~cm}^{-3}$, whereas near the bark, it lies between 0.54 and $0.61 \mathrm{~g} \mathrm{~cm}^{-3}$ (Naji et al., 2011). Basic apparent density, density at $12 \%$ moisture content, and the maximum volumetric shrinkage in the juvenile wood (cores of diameter $0.1 \mathrm{~m}$ with growth rings of approximately less than seven years old) of $H$. brasiliensis are $0.55 \mathrm{~g} \mathrm{~cm}^{-3}, 0.614 \mathrm{~g} \mathrm{~cm}^{-3}$, and $8.2 \%$, respectively (Matan \& Kyokong, 2003). The apparent oven-dried density in juvenile wood of 53-year-old Hevea brasiliensis (similar trees from this study) is $0.621 \mathrm{~g} \mathrm{~cm}^{-3}$, whereas in mature wood, is $0.615 \mathrm{~g} \mathrm{~cm}^{-3}$. The volumetric, tangential, radial, and axial shrinkages in juvenile wood of this species are $7.44,4.88,2.22$ and $0.41 \%$, whereas in mature wood, they are $7.44,4.88,2.22$, and $0.41 \%$, respectively (Severo et al., 2013).

Thermal treatments exposing wood to temperatures approaching $200^{\circ} \mathrm{C}$ for several hours can change its chemical composition. Heating wood at these temperatures, or thermal modification, causes degradation of the hemicelluloses and of the amorphous region of cellulose, contributing to the increase in the degree of crystallinity of this polymer (Arnold, 2010; Bächle et al., 2010; Brito et al. 2008; Calonego et al., 2016; Esteves \& Pereira, 2009; Korošec et al., 2009; Mburu et al., 2008). In addition, a crosslinkage between the lignin and the polymers occurs, which causes the decrease in their hygroscopicity (Esteves et al., 2007; Esteves \& Pereira, 2009; Calonego et al., 2012; Ratnasingam \& Ioras, 2012).

Moreover, juvenile wood is characterized by high lignin content when compared with mature wood and consequently presents an adverse effect on thermal modification (Calonego et al., 2014; Calonego et al., 2016; Severo et al., 2012). H. brasiliensis presents opposite behavior (Severo et al., 2016) due to sugar content in the cell lumen of mature wood (Kadir \& Sudin, 1989).

Thermal modification with steam (thermo hydrolysis) at $180^{\circ} \mathrm{C}$ for $2 \mathrm{~h}$ in wood of Hevea brasiliensis from a $25-30$-yearold plantation in Malaysia showed a decrease in the oven-dried density and the maximum tangential and radial swellings from $11.86 \%, 45.21 \%$, and $11.11 \%$, respectively (Ratnasingam \& Ioras, 2012). However, neither the effects of thermal treatment on juvenile and mature wood nor the various temperatures of treatment on physical properties were studied by the authors.
As the rubber tree presents a high proportion of juvenile and mature woods (Ferreira et al., 2011) and the hygroscopicity and dimensional variation are important factors in the processing and use of wood, the aim of this study was to evaluate the effects of various levels of thermal treatment with heat irradiation on the physical properties of Hevea brasiliensis juvenile and mature woods.

\section{MATERIALS AND METHODS}

Wood specimens for this study were obtained from five 53-years-old Hevea brasiliensis (Willd. ex Adr. de Juss.) Muell. Arg. (Euphorbiaceae) trees, ungrafted from the Miraculous

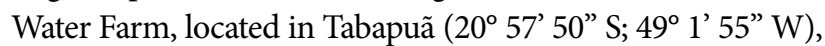
São Paulo, Brazil. The trees were felled at $0.30 \mathrm{~m}$ from the soil and sectioned into $3.0 \mathrm{~m}$ logs. The logs with an average diameter of $37 \mathrm{~cm}$ were cut into flat-sawn boards. Later, the boards were dried down to $10.00 \%$ moisture content in a dry kiln. Five boards containing the pith were cut into $34-\mathrm{mm}$ thick pieces.

\subsection{Thermal treatments of boards}

One dried board taken from each tree was planed to $32-\mathrm{mm}$ thickness and sawed into smaller pieces measuring $0.60 \mathrm{~m}$ in length. Regions with cracks and knots were discarded. One piece 32 by 180 by $600 \mathrm{~mm}$ in size from each board was kept in its original condition (untreated wood) and the other three pieces were used for thermal treatments (thermally modified wood).

A part of the pieces was placed in an electric oven with heat transfer by irradiation, $1-\mathrm{m}^{3}$ net volume, air as inert atmosphere and a programmable controller, and thermally modified in the Laboratory of Wood Drying and Preservation from Unesp, Botucatu, SP, Brazil. Treatment started at an initial temperature of $100^{\circ} \mathrm{C}$ over a period of $14 \mathrm{~h}$ and then the temperature was increased $\left(1.34^{\circ} \mathrm{C} /\right.$ minutes) up to $180{ }^{\circ} \mathrm{C}$ and maintained over a period of $2.5 \mathrm{~h}$ (Severo \& Calonego, 2009). The same procedure was performed with the thermal modification at final temperature of $200^{\circ} \mathrm{C}$ and $220^{\circ} \mathrm{C}$.

After the end of the thermal treatment, the wood pieces were allowed to cool naturally until they reached $30^{\circ} \mathrm{C}$.

\subsection{Specimens preparation}

Standard specimens were removed from all the pieces (untreated and thermally modified) according to the methods in Associação Brasileira de Normas Técnicas' ABNT NBR 7190 (1997) for the physical characterization of juvenile and mature wood. The juvenile wood zone was defined as being located between 40 and $55 \mathrm{~mm}$ from the pith and identified by measurement of fiber length of the $\mathrm{H}$. brasiliensis according to Ferreira et 
al. (2011). Specimens of wood 20 by 30 by $50 \mathrm{~mm}$ in size were removed approximately $25 \mathrm{~mm}$ from the pith and $25 \mathrm{~mm}$ from the bark. Each specimen was cut to perfectly produce tangential, radial, and longitudinal directions and was then measured.

Although the ABNT NBR 7190 (ABNT, 1997) standards state the necessary number of specimens to characterize the physical properties of wood is six, 15 specimens obtained from five boards were used to characterize each treatment (untreated wood and thermally modified woods at $180^{\circ} \mathrm{C}, 200^{\circ} \mathrm{C}$, and $220^{\circ} \mathrm{C}$ ), aggregating 60 specimens for each type of wood.

\subsection{Physical property test of the wood}

The untreated and thermally modified wood specimens were placed in an oven at $103 \pm 2{ }^{\circ} \mathrm{C}$ and were maintained in this condition until their mass stabilization $(0 \%$ moisture content). Subsequently, the specimens were placed in a climatic chamber adjusted to $21 \pm 2{ }^{\circ} \mathrm{C}$ and $65 \pm 5 \%$ relative humidity $(\mathrm{RH})$ until the specimens reached the equilibrium moisture content. The specimens were then weighed and their dimensions measured by using a 0.01 -g accuracy balance and a $0.01-\mathrm{mm}$ accuracy micrometer, respectively. Following these measurements, the specimens were submerged in water until the cell walls were completely saturated. Then the specimens were again measured and weighed. The evaluation of oven-dried density, equilibrium moisture content, and maximum swelling were performed according to the ABNT NBR 7190 (ABNT, 1997) standard.

\subsection{Statistical analysis}

To evaluate differences in oven-dried density, equilibrium moisture content, and maximum swellings, a KolmogorovSmirnov's normality test at $5 \%$ significance was performed. All variables had normal distribution. A parametric two-way test (Anova) at $5 \%$ significance was then performed considering the type of wood (two levels) and the thermal treatment (four levels), as well as Tukey's test at $5 \%$ significance for the comparison of the means.

\section{RESULTS AND DISCUSSION}

Oven-dried density for untreated H. brasiliensis was $0.640 \mathrm{~g} \mathrm{~cm}^{-3}$ for juvenile and $0.638 \mathrm{~g} \mathrm{~cm}^{-3}$ for mature wood (Table 1). The densities of untreated wood presented in this article are similar to those cited by Matan \& Kyokong (2003), Naji et al. (2011), and Severo et al. (2013). The density of untreated mature wood was not different $(p=0.965)$ than that of juvenile wood. This behavior is similar with the one showed by Severo et al. (2013) and Severo et al. (2016), who reported non-influence of the type of wood on density can also be explained by the high levels of extractives content in the juvenile wood when compared with mature wood.

Table 1. Effect of thermal modification temperature on the density and equilibrium moisture content of juvenile and mature woods from Hevea brasiliensis.

\begin{tabular}{|c|c|c|c|c|}
\hline \multirow[b]{2}{*}{ Property } & \multirow[b]{2}{*}{ Untreated } & \multicolumn{3}{|c|}{ Temperature } \\
\hline & & $180^{\circ} \mathrm{C}$ & $200^{\circ} \mathrm{C}$ & $220^{\circ} \mathrm{C}$ \\
\hline \multicolumn{5}{|l|}{ Oven-dried Density $\left(\mathrm{g} \mathrm{cm}^{-3}\right)$} \\
\hline Juvenile Wood, CV & 4.5 & 4.1 & 2.1 & 4.4 \\
\hline Juvenile Wood, Mean & $0.640 \mathrm{a}$ & $0.622 \mathrm{ab}$ & $0.631 \mathrm{ab}$ & $0.612 \mathrm{~b}$ \\
\hline Juvenile Wood, $\downarrow$ (\%) & - & -2.81 & -1.41 & -4.38 \\
\hline Mature Wood, CV & 4.9 & 6.4 & 4.5 & 5.0 \\
\hline Mature Wood, Mean & $0.638 \mathrm{a}$ & $0.628 \mathrm{ab}$ & $0.626 \mathrm{ab}$ & $0.614 \mathrm{~b}$ \\
\hline Mature Wood, $\downarrow$ (\%) & - & -1.57 & -1.88 & -3.76 \\
\hline$\downarrow$ or $\uparrow(\%)$ & $-0.31^{\mathrm{NS}}$ & 0.97 Ns & $-0.79^{\mathrm{NS}}$ & $0.33^{\mathrm{NS}}$ \\
\hline \multicolumn{5}{|c|}{ Equilibrium Moisture Content at $21^{\circ} \mathrm{C}$ and $65 \% \mathrm{RH}(\%)$} \\
\hline Juvenile Wood, CV & 1.8 & 4.0 & 3.2 & 7.6 \\
\hline Juvenile Wood, Mean & $8.98 \mathrm{a}$ & $8.16 \mathrm{~b}$ & $7.75 \mathrm{c}$ & $6.31 \mathrm{~d}$ \\
\hline Juvenile Wood, $\downarrow$ (\%) & - & -9.13 & -13.70 & -29.73 \\
\hline Mature Wood, CV & 1.8 & 3.5 & 3.7 & 8.8 \\
\hline Mature Wood, Mean & $9.23 \mathrm{a}$ & $8.30 \mathrm{~b}$ & $7.81 \mathrm{c}$ & $6.80 \mathrm{~d}$ \\
\hline Mature Wood, $\downarrow(\%)$ & - & -10.08 & -15.38 & -26.33 \\
\hline$\uparrow(\%)$ & $2.78^{*}$ & $1.72 *$ & 0.77 NS & $7.77^{*}$ \\
\hline
\end{tabular}

Means followed by the same letters within rows denote significant difference by Tukey's test at $95 \%$ probability between treatments; ${ }^{*}$ in same column denote significant difference by $\mathrm{F}$ test at $95 \%$ probability between type of wood; same letters within rows and ${ }^{\mathrm{Ns}}$ in same column denote non-significant difference. CV: coefficient of variation; $\uparrow:$ increase; $\downarrow$ : reduction. 
Thermal treatment promotes decreases $(p=0.009)$ of up to $4.38 \%$ and $3.76 \%$ in the oven-dried densities of respective juvenile and mature wood from $H$. brasiliensis when thermally modified at $220^{\circ} \mathrm{C}$.

This fact is explained by the influence of thermal treatment on the changes in the chemical composition by the degradation of extractives and cell wall compounds (Bächle et al., 2010; Brito et al. 2008; Esteves \& Pereira, 2009; Korošec et al., 2009), mainly sugars from hemicelluloses (Brito et al. 2008; Calonego et al., 2016; Severo et al., 2012; Severo et al., 2016) that, consequently, causes weight loss and decrease in apparent wood densities.

These results are consistent with those obtained by Esteves et al. (2007), Arnold (2010), Severo et al. (2012), and Calonego et al. (2014) who thermally modified the juvenile and mature wood from Eucalyptus globulus, Eucalyptus grandis, Fagus sylvatica, Picea abies, Pinus elliottii var. elliottii, and Pinus pinaster.

Respective equilibrium moisture contents (EMC) in the juvenile and mature wood of untreated $\mathrm{H}$. brasiliensis were only $8.98 \%$ and $9.23 \%$ after acclimatized at $21{ }^{\circ} \mathrm{C}$ and $65 \%$ RH. According to Almeida \& Hernández (2006), these lower values in the equilibrium moisture content can be attributed to the phenomenon known as hysteresis.

We found that the EMC of mature wood was significantly higher $(p<0.001)$ than that of juvenile wood. Thus, according to Calonego et al. (2005) and Severo et al. (2012), this result is explained as follows: mature wood has a higher number of hydroxyl groups available to adsorb moisture than juvenile wood.

This study also showed the thermal treatment from $180^{\circ} \mathrm{C}$ to $220^{\circ} \mathrm{C}$ promoted reductions ( $p<0.001$ ) of up to $29.73 \%$ and $26.33 \%$ in the EMC of juvenile and mature wood from rubber wood. Similar improvements were cited by Esteves et al. (2007), Brito et al. (2008), Severo et al. (2012), Calonego et al. (2012), Calonego et al. (2014), and Calonego et al. (2016) for thermally-modified wood of Eucalyptus globulus, Eucalyptus grandis, Eucalyptus saligna, Pinus caribaea var. hondurensis, Pinus elliottii var. elliottii, and Pinus pinaster. According to Esteves et al. (2007), Brito et al. (2008), Esteves \& Pereira (2009), Korošec et al. (2009), and Ratnasingam \& Ioras (2012), chemical changes lead to higher lignin reactivity with formation of crosslinks, responsible for less water absorption, which explain the decrease of equilibrium moisture content.

The volumetric, tangential, radial, and axial swelling in juvenile wood from untreated $H$. brasiliensis was 9.34, 5.56, 2.94 , and $0.62 \%$, respectively. In mature wood, the respective swellings were $9.55,6.05,2.80$, and $0.48 \%$ (Table 2). The tangential and axial swellings of mature wood from untreated rubber wood are statistically different $(p=0.001)$ than that of juvenile wood, whereas the volumetric $(p=0.324)$ and radial ( $p=0.146)$ swellings are not significantly different in both types of wood. We found the axial swelling of juvenile wood was greater $(22.58 \%)$ than that of mature wood.
These results are consistent with those obtained by Matan \& Kyokong (2003), Ratnasingam \& Ioras (2012), and Severo et al. (2013), who studied the dimensional stability of untreated rubber wood. Several authors explain longitudinal swelling can be greater in juvenile wood because this type of wood has greater microfibril angles when compared with mature wood (Bao et al., 2001; Calonego et al., 2014; Severo et al., 2013).

Effect of thermal treatment on the dimensional instability of $H$. brasiliensis wood is shown in detail in Table 2. These results demonstrated that juvenile wood thermally modified at $220^{\circ} \mathrm{C}$ had reductions $(p<0.001)$ of up to $28.59,21.94$, 33.33 , and $56.45 \%$ in the volumetric, tangential, radial, and axial linear swellings when compared with the values found for untreated rubber wood. Mature wood when thermally modified under the same temperature presented reductions $(p<0.001)$ of up to $18.64,19.01,13.57$, and $35.42 \%$ in these respective swellings. Improvement of dimensional stability in the thermally modified wood was explained by Korošec et al. (2009) and Bächle et al. (2010) as resulting from the increases in the degree of crystallinity and the width of cellulose crystallites; and by Esteves et al. (2007), Mburu et al. (2008), Esteves \& Pereira (2009), Arnold (2010), and Severo et al. (2016) due to degradation in the hemicelluloses of the free hydroxyl groups in the amorphous region from cellulose and cross-linking of polymers of wood during thermal treatment.

Influence of thermal modifications presented in our study was smaller than those reported by Ratnasingam \& Ioras (2012), who evaluated thermally modified Hevea brasiliensis treated at $180{ }^{\circ} \mathrm{C}$ between two and $10 \mathrm{~h}$. The difference exists because in this study thermal treatment was performed with steam as an inert fluid and wood having high moisture content. Thus, this variation is consistent with the results of Mburu et al. (2008) and Arnold (2010), who explain that there is an increase in the thermo-degradation of the hemicelluloses by acid hydrolysis under high humidity.

Table 1 and 2 shows in general the influence of thermal treatment at $180^{\circ} \mathrm{C}$ and $200^{\circ} \mathrm{C}$ in juvenile wood was lower than in mature wood. Similar results were reported by Severo et al. (2012) and Calonego et al. (2014) for thermally modified Pinus and Eucalyptus wood. According to the authors, juvenile wood presents an adverse effect on the modification because of its high lignin content when compared with mature wood.

Improvement of dimensional stability in the rubber wood was lower for mature wood than for juvenile wood when thermally modified at $220{ }^{\circ} \mathrm{C}$. These results corroborate those presented by Severo et al. (2016), who concluded the influence of this temperature from thermal treatment in the magnitude of chemical properties of mature wood from $H$. brasiliensis was lower than in juvenile wood. 
Table 2. Effect of thermal modification temperature on the swellings of Hevea brasiliensis juvenile and mature woods.

\begin{tabular}{|c|c|c|c|c|}
\hline \multirow[b]{2}{*}{ Property } & \multirow[b]{2}{*}{ Untreated } & \multicolumn{3}{|c|}{ Temperature } \\
\hline & & $180^{\circ} \mathrm{C}$ & $200^{\circ} \mathrm{C}$ & $220^{\circ} \mathrm{C}$ \\
\hline \multicolumn{5}{|l|}{ Maximum Volumetric Swelling (\%) } \\
\hline Juvenile Wood, CV & 6.0 & 10.1 & 9.0 & 13.1 \\
\hline Juvenile Wood, Mean & $9.34 \mathrm{a}$ & $9.35 \mathrm{a}$ & $9.31 \mathrm{a}$ & $6.67 \mathrm{~b}$ \\
\hline Juvenile Wood, $\downarrow$ or $\uparrow(\%)$ & - & 0.11 & -0.32 & -28.59 \\
\hline Mature Wood, CV & 7.5 & 9.7 & 9.2 & 17.3 \\
\hline Mature Wood, Mean & $9.55 \mathrm{a}$ & $9.12 \mathrm{a}$ & $8.88 \mathrm{a}$ & $7.77 \mathrm{~b}$ \\
\hline Mature Wood, $\downarrow$ (\%) & - & -4.50 & -7.02 & -18.64 \\
\hline$\downarrow$ or $\uparrow(\%)$ & $2.25 \mathrm{NS}$ & $-2.46^{\mathrm{NS}}$ & -4.62 NS & $16.49^{*}$ \\
\hline \multicolumn{5}{|l|}{ Maximum Tangential Swelling (\%) } \\
\hline Juvenile Wood, CV & 9.0 & 10.8 & 9.5 & 19.2 \\
\hline Juvenile Wood, Mean & $5.56 \mathrm{a}$ & $5.74 \mathrm{a}$ & $5.61 \mathrm{a}$ & $4.34 \mathrm{~b}$ \\
\hline Juvenile Wood, $\downarrow$ or $\uparrow(\%)$ & - & 3.24 & 0.90 & -21.94 \\
\hline Mature Wood, CV & 6.6 & 9.9 & 8.2 & 18.1 \\
\hline Mature Wood, Mean & $6.05 \mathrm{a}$ & $5.99 \mathrm{a}$ & $5.84 \mathrm{a}$ & $4.90 \mathrm{~b}$ \\
\hline Mature Wood, $\downarrow$ (\%) & - & -0.99 & -3.47 & -19.01 \\
\hline$\uparrow(\%)$ & $8.81 *$ & $4.36^{*}$ & 4.10 * & 12.90 * \\
\hline \multicolumn{5}{|l|}{ Maximum Radial Swelling (\%) } \\
\hline Juvenile Wood, CV & 23.7 & 23.6 & 22.3 & 11.9 \\
\hline Juvenile Wood, Mean & $2.94 \mathrm{a}$ & $2.92 \mathrm{a}$ & $2.99 \mathrm{a}$ & $1.96 \mathrm{~b}$ \\
\hline Juvenile Wood, $\downarrow$ or $\uparrow(\%)$ & - & -0.68 & 1.70 & -33.33 \\
\hline Mature Wood, CV & 16.9 & 13.5 & 20.0 & 19.1 \\
\hline Mature Wood, Mean & $2.80 \mathrm{a}$ & $2.52 \mathrm{a}$ & $2.51 \mathrm{a}$ & $2.42 \mathrm{a}$ \\
\hline Mature Wood, $\downarrow$ (\%) & - & -10.00 & -10.36 & -13.57 \\
\hline$\downarrow$ or $\uparrow(\%)$ & $-4.76^{\mathrm{NS}}$ & $-13.70^{*}$ & $-16.05^{*}$ & $23.45^{*}$ \\
\hline \multicolumn{5}{|l|}{ Maximum Axial Swelling (\%) } \\
\hline Juvenile Wood, CV & 25.0 & 15.2 & 10.0 & 40.5 \\
\hline Juvenile Wood, Mean & $0.62 \mathrm{a}$ & $0.47 \mathrm{~b}$ & $0.49 \mathrm{~b}$ & $0.27 \mathrm{c}$ \\
\hline Juvenile Wood, $\downarrow$ (\%) & - & -24.19 & -20.97 & -56.45 \\
\hline Mature Wood, CV & 15.3 & 17.5 & 25.1 & 26.1 \\
\hline Mature Wood, Mean & $0.48 \mathrm{a}$ & $0.42 \mathrm{ab}$ & $0.35 \mathrm{bc}$ & $0.31 \mathrm{c}$ \\
\hline Mature Wood, $\downarrow$ (\%) & - & -12.50 & -27.08 & -35.42 \\
\hline$\downarrow(\%)$ & $-22.58^{*}$ & $-10.644^{\mathrm{NS}}$ & $-28.57^{*}$ & $14.81^{\mathrm{NS}}$ \\
\hline
\end{tabular}

Means followed by the same letters within rows denote significant difference by Tukey's test at $95 \%$ probability between treatments; ${ }^{*}$ in same column denote significant difference by $\mathrm{F}$ test at $95 \%$ probability between type of wood; same letters within rows and ${ }^{\mathrm{NS}}$ in same column denote non-significant difference. CV: coefficient of variation; $\uparrow:$ increase; $\downarrow$ : reduction.

Moreover, interaction between type of wood and treatment is not significant for tangential swelling $(p=0.663)$ but is significant to volumetric $(p=0.006)$, radial $(p=0.003)$, and axial $(p<0.001)$ swellings. The significant interaction between type of wood and the treatment, mainly to volumetric, radial, and axial swellings showed thermal modification up to $200^{\circ} \mathrm{C}$ caused less influence on juvenile wood than on mature wood and temperatures of $220^{\circ} \mathrm{C}$ caused opposite behavior.

Previous studies about the chemical properties of untreated rubber wood can help explain this behavior in dimensional stability showed in our study. According to Kadir \& Sudin (1989), this species contains high fructose, glucose, sucrose, maltose, and starch contents in cellular lumen. However, these compounds are relatively low at the central part of the stem (regions where the juvenile wood occurs) and are greater in the periphery (regions where the mature wood occurs). Moreover, according to Shanks \& Gunaratne (2011), heat treatments promote starch gelatinization, which results in lower heat capacity. Thus, these sugars and starches, which are present only in the cellular lumen of periphery of the $H$. brasiliensis stem, can delay the thermal degradation of wood cell wall and, therefore, maintain the mature wood closer to its original condition. Thus, kinetic events related to heat capacity should be examined in future studies with thermally modified wood that contains high starch content.

\section{CONCLUSIONS}

This study showed that thermal modification of Hevea brasiliensis wood decreases its oven-dried density, equilibrium 
moisture content and maximum swellings. The influence of thermal modification at $180-200{ }^{\circ} \mathrm{C}$ in juvenile wood was lower than in mature wood, whereas the thermal modification in juvenile wood at $220{ }^{\circ} \mathrm{C}$ caused a greater variation in its physical properties, such as equilibrium moisture content, and volumetric, tangential and radial swellings. The thermally modified wood is a suitable product for use in environments with high levels of relative humidity.

\section{ACKNOWLEDGEMENTS}

The authors thank Coordenação de Aperfeiçoamento de Pessoal de Nível Superior (CAPES).

\section{SUBMISSION STATUS}

Received: 7 Aug. 2017

Accepted: 25 Oct. 2018

Associate editor: Fernando José Borges Gomes

(1) 0000-0003-0363-4888

\section{CORRESPONDENCE TO \\ Fred Willians Calonego}

Universidade Estadual Paulista Júlio de Mesquita Filho (UNESP), Av. Universitária, 3.780, Altos do Paraíso, CEP 18610-034, Botucatu, SP, Brasil

e-mail: fwcalonego@gmail.com

\section{REFERENCES}

Almeida G, Hernández RE. Changes in physical properties of tropical and temperate hardwoods below and above fiber saturation point. Wood Science and Technology 2006; 40: 599-613. 10.1007/s00226006-0083-8

Arnold M. Effect of moisture on the bending properties of thermally modified beech and spruce. Journal of Material Science 2010; 45: 669-680. 10.1007/s10853-009-3984-8

Associação Brasileira de Normas Técnicas - ABNT. ABNT NBR 7190: projeto de estruturas de madeira. Rio de Janeiro; 1997.

Bächle H, Zimmer B, Windeisen E, Wegener G. Evaluation of thermally modified beech and spruce wood and their properties by FT-NIR spectroscopy. Wood Science and Technology 2010; 44: 421-433. 10.1007/s00226-010-0361-3

Bao FC, Jiang ZH, Jiang XM, Lu XX, Luo XQ, Zhang SY. Differences in wood properties between juvenile wood and mature wood in 10 species grown in China. Wood Science and Technology 2001; 35: 363-375. 10.1007/s002260100099

Bendtsen BA. Properties of wood from improved and intensively managed trees. Forest Products Journal 1978; 28: 61-72.

Brito JO, Silva FG, Leão MM, Almeida G. Chemical composition changes in eucalyptus and pinus woods submitted to heat treatment. Bioresource Technology 2008; 99(18): 8545-8548. 10.1016/j. biortech.2008.03.069
Calonego FW, Severo ETD, Assi PP. Mensuração do comprimento das fibras para a determinação da madeira juvenil em Eucalyptus citriodora. Scientia Forestalis 2005; 68: 113-121.

Calonego FW, Severo ETD, Ballarin AW. Physical and mechanical properties of thermally-modified wood from Eucalyptus grandis. European Journal of Wood and Wood Products 2012; 70(4): 453-460. 10.1007/s00107-011-0568-5

Calonego FW, Severo ETD, Latorraca JVF. Effect of thermal modification on the physical properties of juvenile and mature woods of Eucalyptus grandis. Floresta e Ambiente 2014; 21(1): 108113. 10.4322/floram.2014.004

Calonego FW, Severo ETD, Sansígolo CA, Rezende MA, Bruder EM, Costa VE. Calorific value and chemical properties in juvenile and mature wood of thermally-modified Eucalyptus grandis. Drvna Industrija 2016; 67(3): 207-214. 10.5552/drind.2016.1522

Cown DJ. Corewood (Juvenile wood) in Pinus radiata - should we be concerned? New Zealand Journal of Forestry Science 1992; 22(1): 87-95.

Esteves B, Marques AV, Domingos I, Pereira H. Influence of steam heating on the properties of pine (Pinus pinaster) and eucalypt (Eucalyptus globulus) wood. Wood Science and Technology 2007; 41: 193-207. 10.1007/s00226-006-0099-0

Esteves B, Pereira H. Wood modification by heat treatment: a review. BioResources 2009; 4(1): 370-404.

Ferreira AL, Severo ETD, Calonego FW. Determination of fiber length and juvenile and mature wood zones from Hevea brasiliensis trees grown in Brazil. European Journal of Wood and Wood Products 2011; 69: 659-662. 10.1007/s00107-010-0510-2

Indústria Brasileira de Árvores - IBÁ. Relatório Ibá 2015. São Paulo: Pöyry; 2015.

Kadir AA, Sudin R. Carbohydrates in rubberwood (Hevea brasiliensis Muell.). Holzforschung 1989; 43(3): 173-178. 10.1515/ hfsg.1989.43.3.173

Korošec RC, Lavrič B, Rep G, Pohleven F, Bukovec P. Thermogravimetry as a possible tool for determining modification degree of thermally treated Norway spruce wood. Journal of Thermal Analysis and Calorimetry 2009; 98: 189-195. 10.1007/s10973-0090374-Z

Latorraca JVF, Dünisch O, Koch G. Chemical composition and natural durability of juvenile and mature heartwood of Robinia pseudoacacia L. Anais da Academia Brasileira de Ciências 2011; 83(3): 1059-1068. 10.1590/S0001-37652011005000016

Lobão MS, Costa DP, Almonacid MAA, Tomazello Filho M. Wood quality of Schizolobium parahyba var. amazonicum trees, state of Acre, Brazil. Floresta e Ambiente 2012; 19(3): 374-384.

Matan N, Kyokong B. Effect of moisture content on some physical and mechanical properties of juvenile rubberwood (Hevea brasiliensis Muell. Arg.). Songklanakarin Journal of Science and Technology 2003; 25(3): 327-340.

Mburu F, Dumarçay S, Bocquet JF, Petrissans M, Gérardin P. Effect of chemical modifications caused by heat treatment on mechanical properties of Grevillea robusta wood. Polymer Degradation and Stability 2008; 93(2): 401-405. 10.1016/j. polymdegradstab.2007.11.017 
Naji HR, Sahri MH, Nobuchi T, Bakar ES. The effect of growth rate on wood density and anatomical characteristics of rubberwood (Hevea brasiliensis Muell. Arg.) in two different clonal trails. Journal of Natural Product and Plant Resources 2011; 1(2): 71-80.

Palermo GPM, Latorraca JVF, Carvalho AM, Calonego FW, Severo ETD. Anatomical properties of Eucalyptus grandis wood and transition age between the juvenile and mature woods. European Journal of Wood and Wood Products 2015; 73: 775-780. 10.1007/ s00107-015-0947-4

Ratnasingam J, Ioras F. Effect of heat treatment on the machining and other properties of rubberwood. European Journal of Wood and Wood Products 2012; 70: 759-761. 10.1007/s00107-011-0587-2

Severo ETD, Calonego FW. Thermal modification process for heat radiation to improve the dimensional stability and biological durability of solid wood. Rio de Janeiro: INPI; 2009. Patent PI0902138-8A2.
Severo ETD, Calonego FW, Sansígolo CA. Physical and chemical changes in juvenile and mature woods of Pinus elliottii var. elliottii by thermal modification. European Journal of Wood and Wood Products 2012; 70: 741-747. 10.1007/s00107-012-0611-1

Severo ETD, Calonego FW, Sansígolo CA, Bond B. Changes in the chemical composition and decay resistance of thermally-modified Hevea brasiliensis wood. PLoS ONE 2016; 11(3): e0151353. 10.1371/ journal.pone.0151353

Severo ETD, Oliveira EF Jr, Sansígolo CA, Rocha CD, Calonego FW. Properties of juvenile and mature woods of Hevea brasiliensis untapped and with tapping panels. European Journal of Wood and Wood Products 2013; 71: 815-818. 10.1007/s00107-013-0731-2

Shanks RA, Gunaratne LMWK. Gelatinization and retrogradation of thermoplastic starch characterized using modulated temperature differential scanning calorimetry. Journal of Thermal Analysis and Calorimetry 2011; 106: 93-99. 10.1007/s10973-011-1620-8 